УДК 343.985

DOI https://doi.org/10.32849/2663-5313/2020.2.57

Владислав Негребецький,

канд. юрид. наук,

доиент кафедри криміналістики

Національного юридичного університету імені Ярослава Мудрого

\title{
ВИКОРИСТАННЯ РЕФЛЕКСИВНОГО МИСЛЕННЯ ТА УПРАВЛІННЯ ПІД ЧАС СЛІДЧОГО ЕКСПЕРИМЕНТУ
}

У роботі розглянуто можливості рефлексивної взаємодії між слідчим і особою, показання якої перевіряються під час слідого експерименту. Досліджуються можливості використання методів рефлексивного мислення та управління. Зокрема, рефлексивне управління під час слідчого експерименту може використовуватися слідчм для вирішення таких завдань: 1) управління поведінкою підозрюваного; 2) прогнозування иієї поведінки; 3) побудови слідчим мисленої моделі поведінки підозрюваного у перебігу досліджуваної подї; 4) планування майбутньої слідчої дї; 5) обрання тактичних прийомів, найбільш ефективних і доиільних у конкретній ситуацї; 6) визначення мотивів участі підозрюваного у проведенні такої слідчої дї; 7) викриття неправди в показаннях; 8) запобігання відмови підозрюваного від продовження участі у перевіриі показань на місиі.

Рефлексивне управління передбачає застосування слідчи засобів психологічного впливу на особу, показання якої перевіряються. У роботі сформульовані критерії допустимості засобів психологічного впливу стосовно перевірки показань на місиі: 1) такий вплив не може бути спрямований на примушування особи, показання якої перевіряються, до участі в перевіриі ї показань на місиі; 2) вплив не має обмежувати самостійність дій иієї особи у разі демонстрацї обстановки й окремих дій; 3) не допускається передача їй інформачї навідного характеру.

Під час перевірки показань на місиі ефективність рефлексивного мислення залежить від таких чинників: а) наявності у слідчого відомостей про особу, показання якої перевіряються; б) знання психологї иієї особи; в) повноти інформащї про досліджувані обставини. У роботі виділяються такі стадії використання рефлексивного мислення й управління під час перевірки показань на місиі, як: а) прийнття рішення про проведення слідої дії б) підготовка до проведення перевірки показань на місиі; в) проведення зазначеної слідчої дії. Стосовно кожного з етапів визначені конкретні завдання використання рефлексії. Зроблено висновок про дочільність застосування слідчим прийомів, заснованих на рефлексивному мисленні й управлінні під час перевірки показань підозрюваного на місиі.

Ключові слова: слідча дія, перевірка показань на місці, криміналістичне прогнозування, психологічний вплив, навідна дія.

Постановка проблеми. У криміналістиці не досить досліджувалися проблеми використання рефлексивного мислення під час проведення слідчого експерименту 3 метою перевірки показань підозрюваного на місці події. Разом із тим існували спроби вивчення особливостей використання такого мислення й управління стосовно допиту й обшуку [1, с. 48-55; 2, с. 17-20; 3, с. 32-42; 5, с. 185-197]. У науковій літературі справедливо відзначається, що сфера застосування рефлексивного мислення має поширюватися на різні слідчі дії [2, с. 20].

Мета цісї статті - встановлення особливостей рефлексивної взаємодії між слідчим і особою, показання якої перевіряються, та розробка на цій основі практичних рекомендацій щодо використання методів рефлексивного мислення й управління під час перевірки показань на місці.
У сучасній криміналістичній теорії термін «рефлексія» розглядається як процес самопізнання суб'єктом внутрішніх психічних актів і станів. Він являє собою процес подвоєного, дзеркального взаємовідбиття суб'єктами один одного, змістом якого $\epsilon$ відтворення особливостей один одного [6, с. 838]. Рефлексія включає такі процеси, як проникнення людини в явище чужої свідомості, пізнання його людиною й уявлення, моделювання цих явищ у своєму внутрішньому світі.

Виклад основного матеріалу. Застосування рефлексивного мислення і управління пов'язують в основному із ситуацією конфлікту, коли слідчому протистоїть особа з протилежними інтересами. Необхідно відзначити, що використання рефлексивного мислення й управління під час перевірки показань на місці може характеризуватися як 
конфліктністю, так і безконфліктністю ситуації. Рефлексивне мислення й управління під час цієї слідчої дії можуть використовуватися як у ситуації, коли допитана особа протидіє розслідуванню внесенням свідомо помилкових відомостей у показання, так і в ситуації надання допомоги слідству. Так, використання такого мислення є доцільним у разі усунення суперечностей або перекручень у показаннях.

Рефлексивне мислення і управління під час перевірки показань на місці тісно пов'язані з прогностичною діяльністю слідчого. Рефлексивне управління являє собою конкретне перетворення слідчим напрямів прогнозування [7, с. 21]. Визначивши перспективи і можливості перевірки показань на місці на етапі підготовки до неї, слідчий здійснює управління поведінкою особи, показання якої перевіряються, під час ії проведення. Тому він має уміти передбачати можливі ситуації слідчої дії, поведінку підозрюваного і розраховувати на конкретні результати перевірки. Така діяльність слідчого охоплюється поняттям «криміналістичне прогнозування» [4, с. 663]. Об'єктом прогнозу у цьому разі є діяльність 3 розкриття і розслідування злочину [8, с. 118].

Прогностична діяльність має велике значення для цієї слідчої дії. Так, прогнозування ситуацій майбутньої перевірки показань на місці визначає обрання слідчим власної лінії поведінки, відповідних тактичних прийомів та їх систем. У психологічній літературі відзначається необхідність прогнозування мотивів участі підозрюваного у перевірці показань на місці [9, с. 310]. На нашу думку, воно дає змогу слідчому передбачати небажані мотиви (приміром, бажання підозрюваного заплутати слідство, переконатися в тому, що докази, які мають значення для розслідування, не були виявлені під час огляду місця злочину, втекти під час проведення слідчої дії та ін.)

Роль криміналістичного прогнозування простежується в тих випадках, коли допитана особа погано запам'ятала обстановку. Слідчому треба передбачити, чи зможе вона згадати шлях пересування до місця події і вказати його. Таким чином, прогнозування допомагає слідчому оцінити можливість проведення перевірки показань на місці. Як видається, у цьому разі важливо враховувати індивідуальні психологічні особливості особи, показання якої перевірятимуться, зокрема, здатність сприймати і запам'ятовувати обстановку.

Рефлексивне управління - це двосторонній акт керуючого впливу, заснований на імітації мислення і дій супротивників у кон- флікті [6 с. 838]. Сторони обирають позиції у відповідь на дії протилежної сторони. Процес прийняття рішення включає імітацію мислення і дій останньої, побудову моделей їі поведінки на підставі даних, що є в розпорядженні сторін [7, с. 17]. Така діяльність слідчого охоплюється поняттям «рефлексивне управління». Мета рефлексивного управління полягає в переграванні супротивника. Рефлексивна взаємодія між слідчим та особою, показання якої перевіряються, виявляється в конкретних результатах - викритті неправди в показаннях, відмові цієї особи від попередніх показань і повідомленні нею нових даних. Однак у разі невмілого використання слідчим рефлексивного управління можливі і негативні результати - відмова підозрюваного від продовження участі у проведенні перевірки показань на місці.

Розглядувана слідча дія служить ефективним засобом викриття неправди в показаннях саме завдяки можливостям рефлексивного управління. $\mathrm{У}$ криміналістичній літературі зазначені різноманітні способи обману 3 боку злочинців: а) інсценування одного злочину для приховання іншого; б) інсценування незлочинної події для приховання вчиненого злочинного діяння; в) фальсифікація окремих доказів та ін. [10, с. 251-253]. Одним із таких способів $€$ повідомлення на допиті неправдивих показань. Отже, завданням слідчого є не тільки передбачення мислення і дій підозрюваного, а й здійснення рефлексивного управління його поведінкою з метою викриття неправди в його показаннях. В.О. Коновалова справедливо стверджує, що імітація мислення і дій злочинця поширюється не тільки на сам факт скоєного злочину, а й дає змогу припускати його наступні дії, зокрема, приховання слідів, створення неправдивого алібі, фальсифікацію доказів з метою вказати як на злочинця на іншу особу тощо [11, с. 98$]$.

Рефлексивне управління передбачає використання слідчим засобів психологічного впливу, оскільки такий вплив здійснюється на процес міркування і поведінку протилежної сторони. Під час перевірки показань на місці стосовно засобів психологічного впливу є певні обмеження, пов'язані з особливостями пізнавального процесу цієї слідчої дії. Проблема допустимості засобів психологічного впливу натепер $є$ надзвичайно актуальною. Критерії допустимості засобів психологічного впливу розроблялися в основному стосовно допиту. Вбачаємо доцільним визначити такі критерії для перевірки показань на місці. На нашу думку, вони полягають у такому: 1) такий вплив не може бути спрямований на примушу- 
вання особи, показання якої перевіряються, до участі в перевірці іï показань на місці; 2) вплив не має обмежувати самостійність дій цієї особи у разі демонстрації обстановки і окремих дій; 3) не допускається передача їй інформації навідного характеру. Наведені критерії визначають тактичну схему взаємодії слідчого і особи, показання якої перевіряються. Основним тактичним правилом має бути самостійність дій останньої у виборі маршруту руху і показі об'єктів, якими вона супроводжує свої пояснення. Після прибуття учасників слідчої дії в намічений пункт слідчий пропонує цій особі вказати шлях до місця події, після чого учасники слідують зазначеним нею маршрутом. При цьому особа, показання якої перевіряються, має рухатися попереду слідчої групи, показувати місця й об'єкти, пов'язані з досліджуваними обставинами, й давати пояснення з приводу злочинної події, що тут відбулася. Ця особа мусить вказати межі місця події, обстановку, предмети, пояснити їх зв'язок з обставинами, що перевіряються, а також повідомити по можливості все, що вона згадала, перебуваючи безпосередньо на зазначеному нею місці.

Ефективність у рефлексії тієї або іншої сторони визначається «рангом рефлексії», відповідним її рівнем, що дає змогу перегравати супротивника. На наш погляд, під час перевірки показань на місці ефективність рефлексивного мислення залежить від таких чинників: а) наявності у слідчого відомостей про особу, показання якої перевіряються; б) знання психології цієї особи; в) повноти інформації про досліджувані обставини. Як справедливо відзначається у криміналістичній літературі, ефективність рефлексії залежить від наявності даних про особу злочинця, характер злочину, об'єкт посягання тощо [12, с. 146-147]. Так, В.О. Коновалова і В.Ю. Шепітько підкреслюють, що рефлексивне мислення відрізняється переважно розумовою характеристикою і протікає за схемою імітації розумового процесу супротивника, що грунтується на отриманій інформації про особистісні показники [3, с. 38]. Вибір слідчим правильної лінії поведінки під час проведення перевірки показань на місці значною мірою зумовлений особистістю того, чиї показання перевіряються.

Для здійснення рефлексивного управління в перебігу цієї слідчої дії мають значення дві основні групи відомостей про особу підозрюваного: а) інформація про здібність цієї особи сприймати, запам'ятовувати й орієнтуватися в обстановці і б) дані про іiї психологію. В.Л. Васильєв відзначає, що знання психології підозрюваного допомагає слідчому в налагодженні психологічного контакту, дає можливості уникнути непотрібних конфліктів і одержати під час перевірки показань максимум необхідних доказів [13, с. 472]. Таке знання дає змогу слідчому за допомогою рефлексії контролювати процеси міркування особи, показання якої перевіряються, і запобігати відмови її від участі в цій слідчій дії.

Істотним елементом характеристики рефлексивного управління під час перевірки показань на місці виступає ступінь визначеності рефлексії, що залежить від обсягу доказів по досліджуваних обставинах події, якими володіє слідчий. Так, якщо під час допиту слідчий не отримав інформації про обстановку на передбачуваному місці, то можливості рефлексивного управління з його боку досить обмежені. Цим пояснюється певний ступінь невизначеності рефлексії слідчого $[3$, c.39]. Останній займає позицію, що полягає в одержанні від підозрюваного максимально деталізованих відомостей про обстановку і пов'язані з нею обставини злочинної події.

Можливості рефлексивного управління під час перевірки показань на місці суттєво розширюються, якщо слідчий володіє поряд з показаннями, що перевіряються, інформацією 3 інших джерел: результатами огляду місця події, допитів інших очевидців чи учасників події, перевірок їх показань на місці. Зіставлення отриманих показань 3 такою інформацією дає змогу слідчому заздалегідь намітити слабкі місця в позиції особи, показання якої перевіряються, власну лінію поведінки, тактичні прийоми і їх системи.

Ступінь визначеності рефлексії характеризує рефлексивне управління не тільки з боку слідчого, а й з боку підозрюваного. Можливості цього управління для підозрюваного відчутно збільшуються, якщо він має відомості про обстановку на місці майбутньої слідчої дії. Тому до проведення перевірки показань на місці слідчий мусить вжити необхідних заходів, що виключають будь-яку можливість одержання підозрюваним інформації про обстановку на місці події з інших джерел.

Слід враховувати, що рефлексивна взаємодія між слідчим і підозрюваним має місце ще у процесі допиту, який передує перевірці показань, зокрема, ще до того, як слідчий прийме рішення про проведення цієї слідчої дії. Можна вирізнити такі стадії використання рефлексивного мислення під час перевірки показань на місці, як: а) прийняття рішення про проведення слідчої дії; б) підготовка до проведення перевірки показань на місці; в) проведення зазначеної слідчої діiі. На стадії прийняття рішення про проведення перевірки показань на місці можли- 
вості застосування рефлексивного мислення слідчим спрямовані на з'ясування обставин, що служать підставою для прийняття такого рішення. Вважаємо, що рефлексивне мислення на цій стадії використовується для 1) визначення наявності конфлікту у взаємодії з підозрюваним; 2) з'ясування можливості одержання його згоди на участь у перевірці показань на місці; 3) установлення ступеня і джерел поінформованості підозрюваного про обстановку на місці злочинної події; 4) з'ясування поінформованості цієї особи про докази, якими володіє слідство.

У підготовці до проведення перевірки показань на місці рефлексивне мислення сприяє обранню того чи іншого напряму проведення слідчої дії. Такий вибір залежить від низки чинників, зокрема, від: 1) позиції підозрюваного стосовно слідства; 2) повноти показань в описанні обставин, пов'язаних з обстановкою місця події; 3) тактичних прийомів, які передбачається використовувати; 4) наявності результатів огляду місця події, показань інших осіб, інших доказів, з якими можна зіставити показання; 5) суперечностей (якщо такі є) між показаннями і результатами огляду, іншими доказами; 6) припущень слідчого про місця, де можливо виявити речові докази; 7) часу, що минув з моменту допиту, оскільки є ризик відмови підозрюваного від участі в перевірці його показань на місці; 8) можливості настання надзвичайних обставин (утечі підозрюваного, нападу на слідчу групу тощо). На стадії підготовки до проведення зазначеної слідчої дії рефлексивне управління здійснюється слідчим за такими напрямами, як: 1) переконання підозрюваного в необхідності його участі в перевірці показань на місці; 2) перевірка наявності інших джерел поінформованості цієї особи про обстановку на місці злочинної події; 3) перевірка можливості настання надзвичайних обставин під час проведення слідчої дії.

Під час допиту особа, показання якої перевірятимуться, прогнозує можливості слідчого щодо викриття неправди в її показаннях, імітує його мислення. При цьому можливі різні ситуації, а саме: а) підозрюваний не знає про те, що його показання будуть перевірятися на місці, де відбулась подія злочину; б) йому це відомо; в) підозрюваний знає, що на зазначеному місці проводився огляд. В усіх ситуаціях, намагаючись ввести слідство в оману, він будує помилкову модель події, рефлексивно припускаючи, якою інформацією і з яких джерел може володіти слідчий. Якщо підозрюваному відомо, що його показання будуть перевірятися на місці або що там проводився огляд, то він прагне створити помилкову модель події з вико- ристанням тієї інформації про обстановку, яка йому відома. При цьому можливі різні ситуації: 1) підозрюваний є учасником події; 2) він не є учасником події (має місце самообмова), однак знає обстановку, оскільки побував на цьому місці іншим часом; 3) підозрюваному відомо про обстановку зі слів інших очевидців злочинної події; 4) він взагалі не обізнаний з обстановкою на місці, де відбулася подія. В усіх цих ситуаціях підозрювана особа прагне побудувати помилкову модель події таким чином, щоб уникнути можливих, з іiї погляду, суперечностей між власними показаннями й обстановкою. Якщо ж підозрюваному невідомо про майбутню перевірку показань на місці або про те, що там проводився огляд, можна припустити, що його модель події злочину буде містити суперечності з наявною обстановкою. Ось чому, як видається, доцільно доводити до відома підозрюваного про майбутню перевірку його показань на місці лише після того, як від нього вже будуть отримані докладні свідчення про досліджувані обставини.

Під час проведення цієї слідчої дії застосування рефлексивного управління дає змогу слідчому ефективно контролювати поведінку особи, показання якої перевіряються. У криміналістичній літературі відзначається необхідність здійснення слідчим такого контролю [14, с. 235]. Надання підозрюваному самостійності у виборі маршруту руху, в порядку розповіді відомих йому відомостей і демонстрації окремих дій зовсім не означає, що слідчий не вправі втручатися в перебіг слідчої дії. Практиці розслідування злочинів відомі випадки, коли допитані особи, заявивши про згоду взяти участь у перевірці показань на місці, під час цієї слідчої дії показують зовсім інші місця, які не мають нічого спільного зі скоєним злочином. Саме в такий спосіб вони розраховують послабити, а то й розхитати зібрані слідчим докази, створити можливості для відмови від своїх даних раніше показань у процесі судового розгляду.

У зв'язку з цим необхідним елементом рефлексивного управління під час перевірки показань на місці виступає спостереження за поведінкою особи, показання якої перевіряються. Необхідність такого спостереження була відзначена у криміналістичній літературі [14, с. 233]. Рефлексивне управління поведінкою особи, показання якої перевіряються, під час проведення досліджуваної слідчої дії вирізняється тим, що воно опосередковане психологічним впливом обстановки. Слід якомога уважніше спостерігати за тим, як ця особа пересувається, на які об'єкти і як реагує в цій обстановці. 
Угледівши непослідовність в їі діях, спроби ввести слідство в оману або знищити виявлені сліди, слідчий мусить вжити відповідних заходів. За допомогою рефлексивного управління він може впливати на поведінку особи, показання якої перевіряються.

\section{Висновки}

Рефлексивне управління під час слідчого експерименту з метою перевірки показань підозрюваного може використовуватися для вирішення таких завдань: 1) управління слідчим поведінкою особи, показання якої перевіряються; 2) прогнозування ним поведінки цієї особи; 3) побудови слідчим уявної моделі іiї поведінки у перебігу досліджуваної події; 4) планування ним майбутньої слідчої дії; 5) обрання слідчим тактичних прийомів, найбільш ефективних і доцільних у конкретній ситуації; 6) визначення ним мотивів участі підозрюваного у проведенні цієї слідчої дії; 7) викриття неправди в показаннях; 8) запобігання відмови підозрюваного від продовження участі у перевірці показань на місці.

\section{Список використаних джерел:}

1. Денисюк С.Ф., Шепитько В.Ю. Обыск в системе следственных действий (Тактико-криминалистический анализ) : научно-практическое пособие. Харьков : Консум, 1999. 160 с.

2. Коновалова В.Е. Допрос: тактика и психология. Харьков : Консум, 1999. 157 с

3. Коновалова В.Е., Шепитько В.Ю. Обыск: тактика и психология : учебное пособие. Харьков : Гриф, 1997. 80 с.
4. Шепітько В.Ю. Криміналістика. Енциклопедичний словник (українсько-російський i російсько-український) / За ред. акад. НАН України В.Я. Тація. Харків : Право, 2001.560 с.

5. Ратинов А.Р. Теория рефлексивных игр в приложении к следственной практике. Правовая кибернетика. Москва, 1970. С. 185-197.

6. Велика українська юридична енциклопедія: У 20 т. Харків : Право, 2018. Т. 20: Криміналістика, судова експертиза, юридична психологія / редкол. В.Ю. Шепітько та ін. 952 с.

7. Богинский B.E. Рефлексивное управление при допросе : учебное пособие. Харьков, $1983.41 \mathrm{c}$.

8. Журавель В.А. Криминалистическое прогнозирование в следственно-судебной и оперативно-розыскной практике. Избранные произведения. Харьков : Апостіль, 2016. С. 118-124.

9. Андросюк В.Г. Інформаційно-комунікативні слідчі дії. Юридична психологія : підручник / За ред. Я.Ю. Кондратьєва. Київ : Ін Юре, 2000. C. $298-311$.

10. Ратинов А.Р. Судебная психология для следователей. Москва : НИ и РИО ВШ МООП CCCP, 1967. $289 \mathrm{c}$.

11. Коновалова В.Е. Организационные и психологические основы деятельности следователя Киев : РИО МВД УССР, 1973. 122 с.

12. Коновалова В.Е., Шепитько В.Ю. Криминалистическая тактика: теории и тенденции : учебное пособие. Харьков : Гриф, 1997. 255 с

13. Васильев В.Л. Юридическая психология. 3-е изд. Санкт-Петербург : Питер, 2000. 624 с.

14. Следственные действия (процессуальная характеристика, тактические и психологические особенности) : учебное пособие / А.К. Гаврилов, Ф.В. Глазырин, С.П. Ефимичев и др. Волгоград : ВСШ МВД СССР, 1984. $240 \mathrm{c}$.

The article is devoted to the research of possibility of reflexive interaction between the investigator and the person whose testimony is checked during the investigative experiment. The possibilities of using the methods of reflexive thinking and management are examined. In particular, reflexive control during an investigative experiment can be used by the investigator to solve the following tasks: 1) control the behavior of the suspect; 2) forecasting this behavior; 3) building the investigator's model of the suspect's behavior during the investigated event; 4) planning the future investigative action; 5) the selection of tactics that are most effective and appropriate in a particular situation; 6 ) determining the motives of the suspect's participation in the conduct of this investigative action; 7) exposing lies in the testimony; 8) preventing the suspect from continuing to participate in the verification of testimony at the crime scene.

Reflexive management involves the use of the investigator means of psychological influence on the person whose testimony is checked. The publication sets out the criteria for the admissibility of psychological impact related to the verification of testimony at the crime scene: 1) such an effect cannot be aimed at the coercion of the person whose testimony is verified, to participate in the verification of her testimony at the crime scene; 2) the effect should not limit the autonomy of action of that person in the demonstration situation and individual actions; 3) may not transfer the information of a leading character.

When verifying testimony at the crime scene, the effectiveness of reflexive thinking depends on the following factors: a) whether the investigator has information about the person whose testimony is being checked; $b$ ) knowledge of the psychology of this person; c) completeness of information about the investigated circumstances. The paper highlights the following stages of using reflexive thinking and management when checking evidence at the crime scene: 1) making a decision to conduct an investigative action; 2) preparing for the verification of evidence at the crime scene; 3 ) conducting the specified investigative action. In relation to each of the stages, specific tasks of using reflection are defined. The conclusion is made about the expediency of using investigative techniques based on reflexive thinking and management whenverifying testimony at the crime scene.

Key words: investigative action, verifying testimony at the crime scene, forensic forecasting, psychological impact, suggestive action. 